\title{
The Effect of COVID on Child Maltreatment: A Review
}

\author{
Ami Rokach * and Sybil Chan
}

Department of Psychology, The Center for Academic Studies, Israel and York University, Canada.

Corresponding Author: Ami Rokach, Department of Psychology, The Center for Academic Studies, Israel and York University, Canada.

Received date: September 11, 2021; Accepted date: October 20, 2021; Published date: November 01, 2021

Citation: Ami Rokach and Sybil Chan. (2021). The Effect of COVID on Child Maltreatment: A Review. J Clinical Research and Reports, 9(3); DOI:10.31579/2690-1919/201

Copyright: (C) 2021, Ami Rokach. This is an open access article distributed under the Creative Commons Attribution License, which permits unrestricted use, distribution, and reproduction in any medium, provided the original work is properly cited.

\section{Abstract}

This article addresses child maltreatment during the period where COVID-19 entered our lives in 2020. Repeated lockdowns kept children at home, away from school, from their support systems, and from their routine. Economic difficulties and having to look after the children who were at home were quite onerous on parents. The article explores the reasons that ACE increased during that time, and highlights what can parents, teachers, and the educational system do about it.

Key words: pandemic; child abuse; adverse childhood experiences; children; parents; teachers; educational system

\section{Introduction}

Child abuse is a global issue which impacts millions of children across the world (National Centre for Health Statistics, 2012) [137]. It includes the physical, emotional, and sexual mistreatment of children that are typically inflicted by those in power [225]. Research shows that victims of early abuse are at risk of permitting intergenerational trauma within their own families and communities through aggressive and antisocial behaviours $[11,80,189]$. This form of maltreatment is regarded as an important social issue by the public and threatens the morbidity and mortality by those all involved [26]. Consequently, early adverse experiences are known to place significant threats on children's neural systems [126]. Children faced with adversity are known to have impaired emotional processing systems that makes it challenging them to have trust in others [126]. This hostile attribution bias makes them more vulnerable to other mental health problems, thus, predisposing them to a poorer psychopathology over time [126].

However, the absence of social connection and certainty during the COVID-19 pandemic presents itself as a traumatizing and lifethreatening experience for victims of child maltreatment. Reports of increased anger, frustration, confusion, and PTSD-like symptoms follow the natural progression of abuse to begin and persist [96]. Populations who are most vulnerable to the effects of abuse become subjects of its impact overtime. Even for children who are not the targets of these violent events can still be harmed by its psychological and behavioral inflictions later in life (Vu et al., 2016). Therefore, the drawbacks of social isolation at home may instill risks for children that are subject to experiencing maltreatment when left with their abusers [90].

In fact, $78 \%$ of child abuse and neglect has been found to be perpetrated by the guardians within an immediate household [220]. Further data also shows that this may be dispersed differently across several ethnic backgrounds. Sixty one percent of African American children and $51 \%$ of Hispanic children have experienced at least one ACE [Adverse childhood experience] on average when compared to the Caucasian, non-Hispanic youth [174]. This suggests that children of specific backgrounds are more likely to face ACEs during quarantine, as emerging evidence has found that rates of maltreatment are steadily increasing throughout COVID-19 [31,199].

\section{Previous Research on ACES and Child Development}

Theories detailing the resilience of children maintains that most will be able to overcome a single episode of maltreatment [142]. However, this ability diminishes as risk factors accumulate in their personal lives $[109,119]$. COVID-19 has set a new precedent for risk factors which may impact child development and can be most prominently understood through the consequences of prolonged social isolation. For example, the National Centre for Injury Prevention and Control (NCIPC) and Division of Violence Prevention (2020) note that the combination of heightened family and parenting stress, weakened social connections and social isolation presents several risks for maltreatment to occur [204]. It can be understood through the cumulative risk hypothesis which suggests that greater risks incite a greater prevalence of clinical and developmental issues $[172,175,176]$. This means that children who face multiple adversities are more likely to develop psychological or debilitating conditions as a result.

Specifically, the Isle of Wight Study conducted by Rutter (1979) and colleagues (Rutter et al., 1976) identified six factors which significantly correlate with childhood psychological disorders [172,173]. These include challenges associated with severe marital conflict, large family size, low social status, paternal criminality, maternal mental illness and out of home care placement. It was revealed that no exclusive factor substantially increased the risk for developing a disorder, but rather, an accumulation of these adversities together. A combination of only two factors was found to increase the likelihood of developing a mental 
disorder by fourfold, with four or more factors presenting a 10-fold increase as well $[172,173,175]$. Similar results were shown in the Adverse Childhood Experiences studies which also featured a positive, cumulative relationship between adversity and poor psychophysiological health $[61,65]$.

Poverty and socioeconomic instability have also been related to higher rates of child abuse in the past $[28,140,196]$. Studies have shown that higher rates of binge drinking, domestic violence and overall declines in health are evident during times of economic depression $[28,56,180]$. However, the relationship between these periods of economic downturn and its influence on different types of child maltreatment remains unclear. For example, Seiglie (2004) found that this was only true for cases of neglect, and not for physical abuse [184]. Schenck-Fontaine and colleagues (2017) decided to investigate this relationship further, finding that income inequality was most significantly related to increases in risks of child abuse and maltreatment to occur [178]. Overall, it is evident that the connection between economic decline and violence against children remains complex and requires further research to unravel.

Altogether, these findings reflect concerns made by Bryce (2020) regarding the health of child victims during COVID-19 [24]. Numerous risk factors which exist because of the pandemic may exacerbate pre-existing conditions that are already harmful to maltreated youth. This can be understood through Bromfield et al.'s (2007) term of cumulative harm which describes the exponential effects of accumulated adverse experiences on our health [19]. Bromfield et al.'s (2007) has been used to describe a variety of social issues evident in our society, even including the cumulative harm of global warming due to human and environmental factors $[19,82]$. The same parallels can be drawn as well in the context of child abuse and COVID-19. Children who are now bound to the confines of their abusive household become scapegoats to their perpetrator's frustrations. Threats of unemployment, financial instability and hopelessness for the future may easily evolve into potentially dangerous situations for those in vulnerable positions. Children are no longer protected by institutions who had previously monitored their safety and are now easily accessible by abusers without consequence. Overall, the volatile and potentially harmful circumstances of the COVID-19 pandemic may instill several triggers that can result in cases of abuse and neglect against children $[23,220]$.

\section{The Social Ecological Model of Development during COVID-19}

Interventions directed at minimizing cases of child maltreatment revolve around risk reduction and the promotion of protective factors against victimization $[138,187]$. This can be understood through the social-ecological model of development which organizes factors that interact with and influence children interchangeably throughout their development. For example, the Alliance for Child Protection in Humanitarian Action (ACPHA, 2019) found that pandemics and associated measures taken such as lockdowns drastically alters the environment and associated systems that children exist in. These changes contribute to their heighten vulnerabilities as targets for abuse, neglect, violence, exploitation, and psychological distress (ACPHA, 2019). This is further supported by observations from Fischer et al. (2018) who said, "...disruptions to families, friendships and the wider community can have detrimental consequences for children's well-being, development and their protection" (p. 9) [71].

Additionally, ecological changes in the treatment of children during COVID-19 also reflects distinctive patterns of its promotion of maltreatment and neglect to these individuals [24]. Social norms associated with individuals, families, communities, and societies have since been altered to adapt towards this new normal. In return, research observing the impact of pandemics on child welfare and safety is scarce and lacking. This means that we can only make predictions of these relationships using data from the effects of natural disasters, conflict, and extreme global events on child maltreatment. And by observing the patterns and effects of these circumstances on violence against children, we may be more prepared to reduce its potential for harm during the COVID-19 pandemic.

\section{Disasters and Child Maltreatment}

According to the United Nations International Strategy for Disaster Reduction (UNISDR, 2009), disasters can be understood as disruptions which severely impact the functioning of a community or society [213]. They may result in one or several human, material, economic and environmental losses which negatively contributes to the decline of a community [213]. This can be uniquely illustrated in the context of COVID-19, like with the increased access to children online from virtual abusers. Familial risk factors which contribute to child maltreatment also involves factors like social isolation, family stress (i.e., separation or divorce), violence and parenting stress. This may also be confounded by contributing community factors which are identified as disadvantages associated with one's socio-economic status [204]. By its very nature, the COVID-19 pandemic has clearly cultivated a variety of social, familial, and communal risk factors that contribute to child abuse. Its associated social restrictions confer to the growing amalgamation of adversities evident in vulnerable families and places them at intensified risk of maltreatment [72,127].

However, patterns of maltreatment and abuse against youth are not uncommon during cases of global or national adversity [20,180]. A systematic review by Seddighi et al. (2019) revealed that children exposed to higher rates of violence, social and economic pressures due to natural disasters were more likely to be subjects of child abuse themselves [183]. Consequences associated with these circumstances often threaten the stability of the family unit and has historically featured greater rates of violence against children to occur [13]. This can be clearly seen throughout the 2007-2009 economic recession in the United States, as a rise in head trauma known as 'Shaken Baby Syndrome' was found amongst newborn infants during this $[12,63]$. Other nations have shown different patterns of harm being inflicted onto children, as several countries in West Africa saw a surge in cases of child abuse and teen pregnancies throughout the 2014-2016 Ebola crisis [211]. Altogether, these unique trends may be reflective of violent behaviours associated with prolonged social exclusion (i.e., neglect or rejection) in families with young children during crises [62].

Additionally, pandemics and other disease-related crises often create fearful, uncertain environments which can exacerbate harm against children [215]. These outcomes have been shown have lasting psychological effects on the lives of those involved in these terrible circumstances. For example, parents and children who had quarantined during the H1N1 'Swine Flu' pandemic developed more severe posttraumatic symptoms than those who did not [21]. From this study, it was observed that social isolation was a potential factor for these stressors and has been an imminent problem throughout COVID-19 [21]. Similarly, other commonalities shared between the pandemic and other disasters have also been noted in the literature. This includes things such as: : conditions of vulnerability, the loss of socioeconomic stability and the inability to cope with the negative effects associated with these tragic events (United Nations Office for Disaster Risk Reduction, 2009; Centers for Disease Control and Prevention (CDC), n.d.).

As a result, the critical incident perspective attempts to describe the cumulative, causal relationship which exists between child maltreatment and environmental stressors. To begin, children are believed to be the targets of violent and aggressive behaviors from their caregivers as a response to a sequence of frustrating events like that of COVID-19 $[22,76]$. Burdens such as the threat of poverty, unemployment and so on 
may provoke caregivers to experience higher levels of distress, resulting in poor impulse control that may perpetuate child abuse [24,25]. This was the case in other instances of extreme global disasters such as Hurricane Floyd in 2008, which saw a significant rise of severe brain injuries in children [12]. As such, it is evident that the stressors which follow significant, world changing events disrupt the usual patterns of everyday life and strip individuals of their autonomy. With time, these pressures can result in feelings of overwhelming stress, frustration, and helplessness $[132,206]$. And in return, acts of child abuse may be "...carried out by abusers to compensate for their perceived helplessness or loss of power" [67]. These fickle attempts of sovereignty contribute to the growth of cumulative harm in a child's life and can cause detriments in the longterm health of their development (Miller, 2007). Which, understandably, has been corroborated in the research thus far.

\section{Long-term effects of ACEs and Trauma during COVID-19}

Physical injuries sustained by instances of child maltreatment have also been associated with maladaptive psychological problems such as post-traumatic stress disorder, anxiety, and depression [74]. These issues are often carried into adulthood and inflict damages on various domains of one's life [86,143]. Mental health issues, substance abuse, suicidal ideation and risky sexual behaviour are commonly seen amongst victims of early child abuse and neglect [143]. On average, these individuals typically reach lower educational levels and suffer greater economic hardships [48]. As a result, victims are more likely to become perpetrators themselves and inflict the same abuse they suffered onto their own children and partners [70,222]. For these reasons, the safety of children during the COVID-19 pandemic should be of the utmost priority.

\section{Trauma during COVID-19}

The trauma associated with this pandemic has been linked to the development of serious psychological distress including posttraumatic symptoms and intense fear [21]. This may be worsened for individuals with histories of childhood trauma. Research conducted by Kim and colleagues (2020) has shown that increased risks for depression is evident in populations with ACEs even after controlling for various factors such as quality of life, COVID-19 knowledge, stress coping ability and demographics. Similar studies have also shown that traumatized individuals who perceived the pandemic to be more severe and demonstrated psychological distress from COVID-19 were predicted to have poorer psychiatric outcomes across several countries (Li et al., 2020) $[58,167,185]$. Researchers believe that the combination of learned hopelessness and increased sensitivities to stress create poorer appraisals of taxing circumstances like fears involving infection and mortality $[118,170,219]$. These findings support the idea that individuals with histories of childhood trauma may be at higher risk for developing poorer psychological health during the COVID-19 pandemic - especially with regards to depression and other mood disorders.

Two possible pathways were introduced by Kim et al. (2020) to explain the heightened depressive effects associated with COVID-19 fears and childhood trauma [100]. The first involves the impact of trauma on the body's approach and reactivity to stress. Severe childhood trauma has been known to significantly impact one's natural threshold to stress and alter several physiological mechanisms related to stress reactivity (Heim et al., 2019) [125,135;146]. This involves systems such as our immune and neurological processes, as well as the hypothalamicpituitary-adrenal axis (Heim et al., 2019) [135,146]. As a result, inflictions to these systems by childhood trauma contribute to the risk of developing Major Depressive Disorder [MDD] and pose severe threats to the well-being of individuals [125]. This is especially true during a particularly volatile and especially lonely time like COVID-19 As several brain regions associated with the regulation of emotional appraisals like fear and sadness are impacted by MDD, symptomatic behaviours including feelings of helplessness and victimization may also heighten one's panic of COVID-19 [52,147,153,173,200]. This influx of worries, anxieties and ruminations associated with the pandemic further challenge one's ability to take care of themselves and their families due to the invisible nature of COVID-19. As such, Kim et al. (2020) conclude that significant psychosocial stressors related to the effects of this pandemic may exacerbate troubles present in already vulnerable families and put them at risk of disease susceptibility [100].

\section{$\underline{\text { Suicidality and COVID-19 }}$}

It is apparent that outcomes of the COVID-19 pandemic are predicted to have lasting adverse effects on our physical and mental health (Joiner et al., 2020; Da Silva, 2020). For some, this may lead to permanent, irreversible decisions that will inflict incomprehensible pain to those closest to them. Concerns for suicide were first likened to the increased rates of loneliness, economic stress and anxieties reported by individuals during the early stages of the pandemic (Christodoulou et al., 2012). It left many vulnerable to their own inner demons, and without the aid of healthcare professionals and medical services due to lockdown (Christodoulou et al., 2012). Calls to suicide hotlines were found to have risen during the first year of this global disaster and have not declined since (Chuck, 2020). As such, it is patterns like this which indicate a dangerous and life-threatening path to those without adequate social support throughout the COVID-19 pandemic.

In one example, a man from Illinois was reported to have killed his partner out of suspicions of their contraction of the virus. The stress of this news was enough for him to seek violent means of expressing his anger and ultimately, led to his own death through self-inflicted wounds [8]. Another report based in Pennsylvania shared similar details, with a man committing the murder of his girlfriend due to frustrations of his recent unemployment because of COVID-19 (Burke, 2020). As such, murder-suicides throughout the pandemic were reported to be specifically related to cases of domestic violence and abuse against intimate partners [223]. These cases reflect a chilling trend that puts people at heightened risk of underreported COVID-19 related abuse and neglect [120]. And especially for children, abuse can easily become deadly when understanding that parental abusers are on average, more likely to kill their children under any conditions [87].

\section{COVID-19 on Child Safety}

Children and youth are believed to be at a heightened risk for abuse during COVID-19 as unreported cases of verbal, physical and sexual abuse go unnoticed. A report by Schmidt and Natanson (2020) found that reported cases of child maltreatment had dwindled throughout the pandemic. They proposed that parents and caregivers that inflict harm onto their children are not likely to report their actions, hence, making these instances invisible to the public. Despite this, surges of critical hospital cases related to severe head and body trauma in children was found during the early stages of the pandemics [144,150,179,205,223]. This aligns from data collected by the Centers for Disease Control (CDC, 2020 b) which found a significant increase in child abuse cases across many U.S. emergency department visits throughout early 2020. And while these cases were not classified by maltreatment type, physical abuse is the most prominent form of harm inflicted onto young children which results in hospitalization [103,161,197].

Outreach to anonymous help lines has also become increasingly more common and beneficial for youth experiencing abuse at home during quarantine [89]. In March of 2020 alone, calls related to domestic abuse and violence rose by $30 \%$ in comparison to February of that year [209]. Data from other countries also show a similar trend, with reports relating to child abuse and neglect rising across the globe. Devastatingly, this pattern was found to have incredibly deadly consequences in Fort 
Worth, Texas as a significant rise in severe abuse cases over the course of only one week left two out of seven children dead last year [30].

Articles from other news outlets have also found other devastating patterns of child maltreatment rising as a result of COVID-19 and quarantine. Alex Crowe (2020) of the Canberra times reported that online web content containing child sexual abuse material rose throughout the pandemic [46]. It was found that websites housing this type of media have reported mass crashes since the beginning of the virus's outbreak, with no indication of slowing down. Online perpetrators targeting minors during this time have also shown an upwards trend as well, with the Australian Centre to Counter Child Exploitation suggesting a 123 percent increase as of March 2020 [46]. It is believed greater time spent online is the leading cause of this pattern, with underage children and youth becoming more vulnerable at the hands of unsuspecting offenders without sufficient supervision (Welch \& Haskins, 2020).. Howard Taylor, Executive Director of the Global Partnership to End Violence against Children had commented, “...School closures and strict containment measures mean more and more families are relying on technology and digital solutions to keep children learning, entertained and connected to the outside world, but not all children have the necessary knowledge, skills and resources to keep themselves safe online" (UN News, 2020, p.1) [210]. And with heightened accessibility to the online world, children are more prone to encounter dangerous perpetrators behind their screens. Quadara et al. (2015) believed that online communication serves as a natural environment which can easily facilitate contact between minors and adults [160]. The anonymity of the internet allows abusers to engage in their desires and detach themselves from their behaviors through online aliases. As such, these online personalities may become traps for young, naïve individuals hoping to escape from instances of abuse, parental neglect and substance misuse - making them easy targets for harm $[68,69]$.

Financial strains and instability are also believed to be key contributors to rises of child abuse cases in vulnerable families during COVID-19 [1,3,32,114]. And in times of crisis, children are among the most vulnerable and easily affected populations. This is largely due to their need for safe and stable environments that foster healthy development for achieving critical milestones throughout their early years [117]. In turn, the influx of closures, restrictions and challenges placed onto families during COVID-19 has left many children vulnerable to the effects of the pandemic; resulting in a predicted rise in risks of family violence and abuse are to surge throughout COVID-19 [31,84,96].

Altogether, it is clear that the public's frustrations regarding the safety of abused children during the COVID-19 are not without reason [8]. Factors which contribute to the steady incline of child maltreatment cases may be the result of stressors which impact healthy functioning in families during the pandemic. For example, the closure of many institutions related to child development has left many to remain in the confines of their potentially abusive or toxic environments. Children who previously had the opportunity to escape from their households through youth advocacy centers or crisis hotlines are now bound to experience these tragedies outside the public's eyes [223]. And without the help of these reports, the expected number of cases relating to child abuse or neglect is expected to rise as lockdown continues.

\section{The Consequences of Social Isolation}

Quarantining and isolation protocols can be traced back to its earliest roots in the 12th century [141]. It was first used as a method to combat the spread of leprosy during the early age, and was most recently seen throughout the SARS1 and Ebola crises within the past decade [21,141]. And although its effectiveness in reducing the chances of infection is very high, quarantine does not come without its faults. A review by Đapić et al. (2020), found that mental health problems associated with the early stages of the pandemic included issues like PTSD, anger, frustration, and boredom to ensue [53]. Research has shown that prolonged periods of isolation can intensify these responses and significantly damage the health of individuals in vulnerable populations [181]. This presents itself as a huge problem during pandemic, as social distancing and self-isolation protocols have been regarded as the most common measures to reduce the spread of COVID-19 during the pandemic $[31,215]$.

For most families, this also means that life outside of the home is strictly minimal and prohibited - which is particularly harmful for those residing in abusive or toxic households. Increased time spent within these environments can potentially result in more stressful and intensive contact with abusers - placing children and partners at risk for experiencing physical, sexual and emotional abuse (National Society for the Prevention of Cruelty to Children [NSPCC] [214]. In fact, research by van Gelder and colleagues (2020) found that the combined forces of social isolation, psychological and economic stressors as well as increases in negative coping mechanisms (i.e., excessive drinking) contribute significantly to the occurrence of family violence [215].

These findings are incredibly important when disseminating other social trends found during this hostile time. For instance, alcohol sales in Australia rose more than 36\% when quarantine measures were enforced at the peak of the pandemic (Common wealth Bank Group, 2020). This was likely due to the closure of establishments that allowed for the consumption of alcohol to occur under social situations. In turn, the threat of unemployment, financial strains and social isolation may encourage individuals to turn towards substances like alcohol to cope with these new realities $[99,165]$. Thus, increasing the likelihood of family violence to become a reality. In fact, $61 \%$ of parents have admitted to shouting and/or screaming at their child at least one time during the beginning of the pandemic [108]. More disturbingly, one in six have reported physically assaulting their child, with over $11 \%$ having repeated this action more than once [108].

Alternatively, the consequence of social isolation and physical distancing measures poses several risks to our mental and physical health as well. In previous epidemics, we have seen a surge of various mental health concerns rise in response to national and global disasters of the past $[77,83,106,207]$. The same is to be predicted with COVID-19, as mentioned by Galea and colleagues (2020) [78]. Researchers believe that significant increases in anxiety, depression, substance use, loneliness, and domestic violence will occur throughout the course of the pandemic. These influences all contribute to the very real possibility of children being in danger of abusers during such challenging times.

In fact, research by Rosenthal and Thompson (2020) contend that social isolation, or more accurately known as physical distancing measures, has been proven to pose great harms to children in abusive environments [168]. Observations made by by Campbell (2020) found that substantial rises of family violence reports in America were significantly related to the social isolation restrictions placed onto individuals throughout COVID-19 [31]. This may be attributed to the closures of organizations and social services that typically offer support to these victims like teachers and extended family members [168]. As such, perpetrators of family violence are now able to conduct their maltreatment within the confines of their home. And signs that may indicate instances of abuse are now concealed from the public and are less likely to encourage support from others to stop it [193]. As such, governments and other ruling bodies must recognize the increased risks for violence to ensue during COVID-19 and to encourage citizens to report such cases whenever possible [214]. Without these aids, it is unlikely for these cases to be recognized and in turn, largely remain unreported within these households. As such, the need for social connection has never been so necessary than at a time like this, with 
support from friends and family being the true instigators of change for the trajectory of the abused.

\section{COVID-19 and Family Stress}

Public health measures designed to help mitigate the spread of COVID-19 have disrupted the ecological systems that children develop throughout their early childhood [5,47]. The disruption of social services, closures of schools and the erosion of family and community supports typically active in a child's live have been altered with throughout the pandemic. Coupled with these limitations, contextual stressors which are evident in most during COVID-19 have led to the development various mental health challenges. Feelings of distrust, uncertainty about the future and economic instability have significantly negative ramifications for the psychological health of families and youth [21]. This includes the development of post-traumatic stress symptoms, anger and fear [51].

\section{Caregiver Stress and Burnout during COVID-19}

As an estimated 74 million children under the age of 18 reside with their parents in the United States, it is clear that the challenges associated with the restrictions of the COVID-19 pandemic have substantial threats to the wellbeing of caregivers across the nation (U.S. Bureau of the Census, n.d.). This is seen most prominently in relation to the economic decline suffered by many across the globe. Over half $(53 \%)$ of American adults reported having financial difficulties during the start of the pandemic [155]. Logically, this places parents at-risk for feeling 'burnt out' or overwhelmed with their caregiving roles. This can be understood as a prolonged response to stress that affects an average of 5$20 \%$ of parents $[2,129,163,169,198]$. Parental burn out features severe physical and emotional consequences that include decreased sleep quality, time spent with family, poorer confidence in caregiving roles and hopelessness [95,130,169]. According to Mikolajczak and Roskam (2018), the Balances between Risks and Resources theory posits that burnout begins when a mismatch between parenting-related demands, resources, and expectations of one's role in these circumstances occur [169]. And when chronically imbalanced, the likelihood of parental burnout occurring becomes more likely to happen.

Research has also shown that parents who are constantly stressed may also face greater troubles handling healthy relationships with their partners and children [17,128,129]. Specifically, parents who scored higher on measures of parental burnout report experiencing higher levels of escapism, suicidal ideation and conflicts with their partner [129]. Results from this study also indicated that these parents engaged in higher levels of child abuse and neglect. It is believed, then, that associations of child abuse and burnout fall in tandem with each other. This is further supported by Brianda and colleagues (2020) who found that levels of child abuse could be controlled and minimized through proper interventions aimed at reducing feelings of parental burnout [17].

Additionally, a unique between different parenting styles, parental burnout and child abuse has also been shown by Rodriguez (2020) [167]. Parents who are reportedly more overreactive, harsh and authoritarian with their caregiving style were found to engage in greater reports of child abuse [167]. However, its relationship with parental burnout remains less clear. Parents experiencing high levels of parental burnout typically do not endorse the use of harsh punishment on their children, but often feel guilty when engaging in such behaviours $[128,130]$. They report feeling fearful for the safety of their children when alone in their care, with similar reports being made with regards to lax and neglectful parenting behavior. In turn, the mental and physical exhaustion associated with parental burn out may play an important role when understanding the triggers of child abuse and neglect despite the parenting style used within the household. These findings all align with the idea that all parents can become abusive under certain circumstances, making COVID-19 an incredibly dangerous time for children and youth
[49,92,116,190]. For example, parents of school aged children (4-10 years) who had experienced job loss during the pandemic reported exhibiting increased abusive behavior towards their children (Lawson et al., 2020). This included physical behaviors ranging from corporal punishment (i.e., spanking) to even severe physical abuse like assault. Reports from several online crisis lines saw an overwhelming proportion (79\%) of minors that disclosed residing with their abuser(s) during quarantine [115,162]. A staggering $40 \%$ increase in calls made to confidential hotlines were shown in May 2020 when compared to May 2019 (Childhelp, 2020) [37]. About half of all web and chat correspondences during this period were initiated by youth 13 to 17 years of age for of concerns including (38\%), physical (32\%), and sexual (12\%) abuse [37].

Consequently, demands during the COVID-19 pandemic can be easily understood as risk factors that contribute to caregiver stress [159]. This may include things such as unemployment, financial insecurity, a lack of social support from others and the inability for leisure (Parkes et al., 2015) $[43,112,118,195]$. Restrictions placed onto resources that parents heavily depended on, including day cares, schools and community-based programs also play a huge role in the mental and physical exhaustion typically experienced by caregivers during the pandemic (Cameron et al., 2020) [44,129]. In turn, parental duties have increased significantly due to closures during this time that have left children in the hands of their caregivers 24 hours a day, seven days a week. This can be incredibly challenging given the circumstances of work, leisure, and self-care that caregivers are also responsible for in their personal life. For example, data shows that parents may be working an upwards of three additional hours per day during their pandemic working schedules [55]. This is particularly problematic, as resources that help buffer the effects of burnout like attending fitness/community centres, churches and restaurants have largely remained closed during COVID19. Without these guards, parents will face difficulties in balancing their personal, professional, and parental responsibilities that will lead to eventual burnout - especially in those with perfectionistic tendencies (Parkes et al., 2015) [91,118].

\section{Domestic Violence and COVID-19}

Results from several studies showed that significant increases in IPV ([intimate partner violence] related calls across the world were made to law enforcement following the emergence of COVID-19 $[4,60,101,108]$. This means that child exposure to IPV was likely to have increased as well, with distinct surges in calls to crisis lines for children being seen during this time [136,157]. Changes in these tense environments may lead to exploitative relationships that are confined within the home due to reduced accesses to necessary health services. As such, victims of abuse may be forced to remain trapped with their abusers and suffer from non-accidental injuries (NAIs) that lead to increased risks of several medical and psychological problems $[45,65,81,182]$.

Anecdotal evidence from several countries including the U.S., Brazil, China, and Australia have also seen significant growth in cases of child abuse and intimate partner violence due to quarantining at home $[31,215]$. In China specifically, rates of domestic violence were found to have risen threefold during February of 2020 with no signs of stagnation [4]. Measures taken by European authorities have sought to reduce these escalating numbers as well. In Italy and France, governmentcommissioned hotels were offered to those in abusive households (Reuters News Agency, 2020) [54]. This was done to combat the evergrowing pool of victims that surged during the beginning of the pandemic. Similar trends were also seen in the UK, as reports of domestic violence also increased during COVID-19. Countries in North America were also subjugated to comparable numbers of growth, as cases of family violence in various states in the U.S. were found to increase by a staggering $21 \%$ $31 \%$ in 2020 alone [217]. The significance of this data proves that risks 
of abuse during quarantine present very real threats to those trapped in these circumstances and their livelihoods.

\section{Schools and COVID-19}

Children are also more vulnerable at the hands of their abusers due to the closures of schools and institutions that generally report this type of behaviour (Fraihat v U.S. Immigration and Customs Enforcement, 2020). Schools traditionally served as an alternative space for educators to supervise and protect children from harm (Making Caring Common Project, 2020) [5,68]. Those that were suspected of abuse or neglect were able to be identified, and thus, supported through their tragic circumstances. However, lower cases of child abuse were reported during the last week of March 2020 at the start of the pandemic [88]. And while some may interpret this as a positive trend, many believe that this is the outcome of absent reports. $22 \%$ of suspected child maltreatment cases in February of 2020 were made by school staff members [88]. This number dropped to $7 \%$ in the following month proceeding social isolation laws mandated by the federal government [88]. It is likely that challenges associated with communications to these victims prevent them from seeking help. Or, if discovered, may actually be more threatening to their livelihoods than previously before [158].

Overtime, several institutions have begun to recognize this problem and have started to implement policies designed for promoting child safety and protection. For example, some schools in Spain have enacted "open door" policies provide safe and supportive environments for children suspected of child abuse or neglect [166]. This involves a sixstep action plan which is aimed at promoting dialogue concerning the challenges, risks, and consequences of unhealthy confinement at home. The benefit of this movement helps educate children on the signs of abuse, and what they can do to protect themselves [218]. This allows the stigmatization of child maltreatment to become normalized and understood as something that can be prevented.

Other approaches designed to reduce maltreatment against children includes the promotion of zero violence beliefs at an early age. Mottos such as, "Treat others how you would like to be treated" and "Reporting violence does not make you a snitch, it makes you brave" help socialize children to learn violence is never justified and that individuals with high morals are most well desired [23,145]. This can be further enforced by teachers who are educated on recognizing early signs of abuse, as they can promote positive messages about healthy relationships and provide them with resources to use if they are in danger [201,228]. Therefore, ensuring that the school space remains as an environment which advocates for child safety and welfare.

Research on child abuse prevention is clearly pointing to the need to equipping children with greater protective skills, while society does all it can to ensure the safety of children [68]. Consequently, many child abuse prevention trainings also target all school staff, families, and community members [16]. Bryant et al. (2020) have, in their study, implemented "opening doors" in schools to foster supportive relationships and a safe environment to prevent child abuse during COVID-19 confinement [23]. Their approach included: dialogic workspaces, dialogic gatherings with students, class assemblies or mentoring, dialogic pedagogical gatherings with teachers and community, mixed committees and community networks, and social network dynamization with preventive messages and the creation of a sense of community. These actions include elements identified by previous research on effective school-based programs to prevent child abuse and encourage the preventive socialization of violence.

Clearly, it is evident that further research and proactive change must be done to equip children with greater skills to protect themselves from harm [68]. This requires the need for all members of a child's early life to be involved in this process. For example, several child abuse prevention programs involve school staff, families, and community members so that everyone is informed on what must be done in cases of abuse against children [16]. This is reflective of work conducted by Bryant et al. (2020), who sought to promote dialogue and social systems aimed at preventing child maltreatment through education and community-based resources [23]. Schools can become trusted environments that engage families and larger communities to share the responsibility of keeping children safe against abuse similarly to what teachers do already $[69,171]$. According to Oliver (2020), teachers play a significant role in supporting children suffering from abuse. They may conduct daily wellness or 'follow-up' calls with students who are suspected of harm and ensure that they supported throughout this time. Educators have also been known to encourage dialogues regarding abuse and violence prevention through school assemblies, classes and private conversations $[41,75,202]$. These instances allow children to place faith in their teachers and promote more positive relationships to emerge [23].

\section{Helping Abused Children during COVID-19}

Reducing the effects of cumulative risk and harm against children during the COVID-19 pandemic requires progressive action against the factors which perpetuate violence experienced by at-risk children [24,159]. Families which are disadvantaged in essential needs relating to housing, transport and medical support must be addressed to minimize the long-term implications related to the cycle of abuse and maltreatment [14,24]. Suggestions made by Bryce (2020) believed that greater social support provided by child welfare agencies must be at the focal point of such a movement to reduce the inequities faced by abused youth [24,187]. This involves the mobilization of social networks which help protect individuals against the negative, environmental pressures that are evident in their lives $[98,156]$.

For example, telecommunication using online platforms like Zoom can be used as a safe and alternative form of remote contact for those limited by social distancing protocols [93,113]. This can be easily arranged for those may be separated from their parents and be done in secrecy. Technology has also been shown to be an effective method for administering parental training as well [6,7]. High-risk and low-income mothers were reported to engage in these services due to the flexibility it provided for them [7]. Findings like this share much potential in a pandemic world, as many are forced to juggle their work and personal lives all within the confines of their homes.

Following this, social media and other online platforms may also serve as a positive tool to help enable people's feelings of control and mastery during these challenging times. This can be seen through posts which encourage people to make significant changes in their lives, which is also known as the empowerment approach [208,230]. By promoting feelings of power, competency and positive self-worth, individuals can find the strength within themselves to make proactive changes in their lives. For the abused, this may involve finding the optimal balance between protecting themselves from their toxic environments and the challenges associated with physical distancing and lockdown measures from the pandemic.

As such, it is imperative that appropriate and proactive measures are made to address the restricted delivery of child welfare services to youth in need of help during COVID-19. Online media can be implemented to educate the public on how to spot and report abuse when it is suspected during COVID-19. This can make child safety and protection a shared responsibility that can be governed by our neighbors, colleagues and friends when deceptively hidden from law enforcement. Therefore, making it easier for children to be protected during a particularly isolating time such as this. Final Thoughts

Altogether, concerns for the increased risk of maltreatment against children is evident during a time like COVID-19 (The Alliance 
for Child Protection in Humanitarian Action, 2020). No longer are we able to freely interact with others in the physical world without fears of infection and political dissent [225]. And no longer can children be protected from abusers that lurk in their physical and online spaces during lockdown [59]. There are, thus, worries regarding the sexual exploitation of children online, as our dependency on technology steadily increases with each passing day.

As a result, the COVID-19 pandemic fosters many risk factors that promote child abuse and neglect to occur. These influences can be identified from the following:

(a) Children who display lower self-esteem or somatic symptoms that require additional aid or emotional support [133,134].

(b) Parents with mental health or developing psychological issues that include the misuse of addictive substances [124].

(c) Financial or existential problems associated with healthrelated crises [148].

(d) Heightened levels of stress in response to viral epidemics or infections [10].

(e) Pre-existing problems or patterns of poor family functioning $[62]$.

Clearly, social distancing measures designed to eradicate the spread of COVID-19 has also left many vulnerable to vicious environments that house intrafamily violence and abuse $[36,53,57,107,151,227]$. It is particularly rampant when stressors like economic instability, disease-related fears, exposure to exploitative relationships and reduced social support are present during a pandemic [152]. Especially during COVID-19, social isolation can exacerbate these instances as victims are placed in vulnerable situations without the support of others at their aid [215].

As such, it is necessary that protective factors which buffer the effects of child maltreatment during COVID-19 is addressed to reduce its risks on the livelihoods of youth across the world. Things such as the provision of a supportive family environment, stable parental employment and access to necessary health and social services are all factors that help children remain safe during such unprecedented times [204]. And although it is undeniable that all these factors were significantly affected throughout COVID-19, there is still time to learn from this period in history and implement change to help defend these children from harm.

\section{References}

1. Abedi, V., Olulana, O., Avula, V., Chaudhary, D., Khan, A., Shahjouei, S., Ji, J., \& Zand, R. (2021). Racial, economic, and health inequality and COVID-19 infection in the United States. Journal of Racial and Ethnic Health Disparities, 8, 732-742.

2. Abidin, R. R., Zalaquett, C. P., \& Wood, R. J. (1997). Evaluating stress: A book of resources. Scarecrow Education.

3. Agrawal, N. \& Kelley, M. (2020). Child abuse in times of crises: Lessons learned. Clinical Pediatric Emergency Medicine, 21(3), 100801.

4. Allen-Ebrahimian, B. (2020, May 7). China's domestic violence epidemic. Axios.

5. Anderson, R. M., Heesterbeek, H., Klinkenberg, D., \& Hollingsworth, T. D. (2020). How will country-based mitigation measures influence the course of the COVID-19 epidemic? The Lancet, 395(10228), 931-934.

6. Baggett, K. M., Davis, B., Feil, E. G., Sheeber, L. B., Landry, S. H., Carta, J. J., \& Leve, C. (2010). Technologies for expanding the reach of evidence - based interventions:
Preliminary results for promoting social - emotional development in early childhood. Topics in Early Child Special Education, 29(4), 226 - 238.

7. Baggett, K. M., Davis, B., Feil, E., Sheeber, L., Landry, S., Leve, C., \& Johnson, U. (2017). A randomized controlled trial examination of a remote parenting intervention: Engagement and effects on parenting behavior and child abuse potential. Child Maltreatment, 22(4), 315 - 323.

8. BBC News. (2020, June 1). Coronavirus lockdown 'perfect storm' for abused children - Sajid Javid.

9. Becker-Blease, K. A., Turner, H. A., \& Finkelhor, D. (2010). Disasters, victimization, and children's mental health. Child Development, 81(4), 1040-1052.

10. Beekman, J. B., Stock, M. L., \& Marcus, T. (2016). Need to belong, not rejection sensitivity, moderates cortisol response, self - reported stress, and negative affect following social exclusion. The Journal of Social Psychology, 156(2), 131 - 138.

11. Berger, L. M., \& Waldfogel, J. (2011). Economic determinants and consequences of child maltreatment. OECD Social, Employment and Migration Working Papers, 111.

12. Berger, R. P., Fromkin, J. B., Stutz, H., Makoroff, K., Scribano, P. V., Feldman, K., Tu, L. C., \& Fabio, A. (2011). Abuse head trauma during a time of increased unemployment: A multicenter analysis. Pediatrics, 128(4), $637-643$.

13. Biswas, A., Rahman, A., Mashreky, S., Rahman, F., \& Dalal, K. (2010). Unintentional injuries and parental violence against children during flood: A study in rural Bangladesh. Rural and Remote Health, 10(1), 1199.

14. Bliss, D. L., \& Meehan, J. (2008). Blueprint for creating a social work-centred disaster relief initiative. Journal of Social Service Research, 34(3), 73-85.

15. Boddy, J., Young, A., \& O'Leary, P. (2020, March 12). 'Cabin fever': Australia must prepare for the social and psychological impacts of a coronavirus lockdown. The Conversation.

16. Brassard, M. R., \& Fiovanti, C. M. (2015). School-based child abuse prevention programs. Psychology in the Schools, 52(1), 40-60.

17. Brianda, M. E., Roskam, I., Gross, J. J., Franssen, A., Kapala, F., Gérard, F., \& Mikolajczak, M. (2020). Treating parental burnout: Impact of two treatment modalities on burnout symptoms, emotions, hair cortisol, and parental neglect and violence. Psychotherapy and Psychosomatics, 89(5), 330-332.

18. British Broadcasting Corporation [BBC]. (2020, March 30). Coronavirus: 'Domestic abuse pandemic likely due to shutdown'. Retrieved April 4, 2020.

19. Bromfield, L. M., Gillingham, P., \& Higgins, D. J. (2007). Cumulative harm and chronic child maltreatment. Developing Practice: The Child Youth and Family Work Journal, 19, 3442.

20. Brooks - Gunn, J., Schneider, W., \& Waldfogel, J. (2013). The great recession and the risk for child maltreatment. Child Abuse \& Neglect, 37(10), $721-729$.

21. Brooks, S. K., Webster, R. K., Smith, L. E., Woodland, L., Wessely, S., Greenberg, N., \& Rubin, G. J. (2020). The psychological impact of quarantine and how to reduce it: Rapid review of the evidence. The Lancet, 395(10227), 912 - 920.

22. Browne, K. (2002). Child abuse: Defining, understanding and intervening. In Wilson, K. \& James, A. (Eds.), The child protection handbook (pp. 50-70)

23. Bryant, D.J., Oo, M. \& Damian, A.J. (2020). The rise of adverse childhood experiences during the COVID-19 pandemic. Psychological Trauma: Theory, Research, Practice, and Policy, 12(S1), S193-S194. 
24. Bryce, I. (2020). Responding to the accumulation of adverse childhood experiences in the wake of the COVID-19 pandemic: Implications for practice. Children Australia, 45, 80-87.

25. Bugental, D. B., Mantyla, S. M., \& Lewis, J. (1989). Parental attributions as moderators of affective communication to children at risk for physical abuse. In Cicchetti, D. \& Carlson, V. (Eds.), Child maltreatment: Theory and research on the causes and consequences of child abuse and neglect (pp. 254279). Cambridge University Press.

26. Buljan Flander, G., Čorić, V. i Štimac, D. (2008). [Experience, knowledge and attitudes of primary care physicians in the Republic of Croatia and child abuse and neglect]. Suvremena Psihologija, 11(2), 313-328.

27. Burgard, S. A., \& Kalousova, L. (2015). Effects of the great recession: Health and wellbeing. Annual Review of Sociology, 41, 181-201.

28. Burgard, S. A., Seefeldt, K. S., \& Zelner, S. (2012). Housing instability and health: Findings from the Michigan Recession and Recovery Study. Social Science \& Medicine (1982), 75(12), 2215-2224.

29. Cacioppo, J. T., Hawkley, L. C., Ernst, J. M., Burleson, M., Berntson, G. G., Nouriani, B., \& Spiegel, D. (2006). Loneliness within a nomological net: An evolutionary perspective. Journal of Research in Personality, 40(6), 1054-1085.

30. Calaway, J. (2020, March 22). Spike in severe child abuse cases likely result of COVID-19. Checkup News Room. Retrieved April 4, 2020.

31. Campbell, A. M. (2020). An increasing risk of family violence during the COVID-19 pandemic: Strengthening community collaborations to save lives. Forensic Science International: Reports, 2, 1000089.

32. Center on Budget and Policy Priorities. (2021, June 16). Tracking the COVID-19 recession's effects on food, housing, and employment hardships.

33. Center on the Developing Child at Harvard University. (2016). Building core capabilities for life: The science behind the skills adults need to succeed in parenting and in the workplace. Harvard University.

34. Centers for Disease Control and Prevention. (2020, May 13). People with certain medical conditions.

35. Centers for Disease Control and Prevention. (n.d.). Risk and protective factors.

36. Cherry, R., \& Wang, C. (2016). The link between male employment and child maltreatment in the U.S., 2000 - 2012. Children and Youth Services Review, 66, 117 - 122.

37. Childhelp. (2020). Hotline impact report.

38. Christodoulou, C., Douzenis, A., Papadopoulos, F. C., Papadopoulou, A., Bouras, G., Gournellis, R., \& Lykouras, L. (2012). Suicide and seasonality. Acta Psychiatrica Scandinavica, 125(2), 127-146.

39. Chuck, E. (2020, April 4). 'Hard for helpers, too': Faced with their own Coronavirus fears, crisis hotline counselors answer surge in calls. NBC News.

40. Clay, R. A. (2020, March 18). COVID-19 isn't just a danger to older people's physical health. American Psychological Association.

41. Coker, A. L., Bush, H. M., Cook-Craig, P. G., DeGue, S. A., Clear, E. R., Brancato, C. J., Fisher, B. S., \& Recktenwald, E. A. (2017). RCT testing bystander effectiveness to reduce violence. American Journal of Preventive Medicine, 52(5), 566-578.

42. Commonwealth Bank Group. (2020, March 30). An early look at how the Coronavirus is affecting household spending. Commbank.
43. Courtin E., Allchin E., Ding A.J., Layte R. (2019). The role of socioeconomic interventions in reducing exposure to adverse childhood experiences: A systematic review. Current Epidemiology Reports, 6, 423-441.

44. Craig, L., \& Churchill, B. (2020). Dual-earner parent couples' work and care during COVID-19. Gender, Work, and Organization. Advance online publication.

45. Cross, D., Vance, L. A., Kim, Y. J., Ruchard, A. L., Fox, N., Jovanovic, T., \& Bradley, B. (2018). Trauma exposure, PTSD, and parenting in a community sample of low-income, predominantly African American mothers and children. Psychological, 10(3), 327-335.

46. Crowe, A. (2020, June 7). Child abuse websites crash during coronavirus lockdowns. The Canberra Times.

47. Cuartas, J. (2020). Heightened risk of child maltreatment amid the COVID-19 pandemic can exacerbate mental health problems for the next generation. Psychological Trauma: Theory, Research, Practice, and Policy, 12(1), S195-S196.

48. Currie, J., \& Widom, C. S. (2010). Long-term consequences of child abuse and neglect on adult economic well-being. Child Maltreatment, 15(2), 111-120.

49. Curtis, T., Miller, B. C., \& Berry, E. H. (2000). Changes in reports and incidence of child abuse following natural disasters. Child Abuse \& Neglect, 24(9), 1151-1162.

50. Da Silva, C. (2020, March 25). Crisis helpline sees surge in messages from young people anxious over Coronavirus. Newsweek.

51. Danese, A., Smith, P., Chitsabesan, P., \& Dubicka, B. (2020). Child and adolescent mental health amidst emergencies and disasters. The British Journal of Psychiatry, 216(3), 159-162.

52. Dannlowski, U., Stuhrmann, A., Beutelmann, V., Zwanzger, P., Lenzen, T., Grotegerd, D., Domschke, K., Hohoff, C., Ohrmann, P., Bauer, J., Lindner, C., Postert, C., Konrad, C., Arolt, V., Heindel, W., Suslow, T., \& Kugel, H. (2012). Limbic scars: Long-term consequences of childhood maltreatment revealed by functional and structural magnetic resonance imaging. Biological Psychiatry, 71(4), 286-293.

53. Đapić, M. R., Flander, G. B., \& Prijatelj, K. (2020). Children behind closed doors due to COVID-19 isolation: Abuse, neglect and domestic violence. Archives of Psychiatry Research, 56(2), 181-192.

54. Davies, S., \& Batha, E. (2020, March 26). Europe braces for domestic abuse 'perfect storm' amid coronavirus lockdown. Thomson Reuters Foundation News.

55. Davis, M. F., \& Green, J. (2020, April 23). Three hours longer, the pandemic workday has obliterated work-life balance. Bloomberg.

56. Dee T. S. (2001). Alcohol abuse and economic conditions: evidence from repeated cross-sections of individual-level data. Health Economics, 10(3), 257-270.

57. Delaleu, N. (2020, July 4). COVID-19: Stopping the rise in domestic violence during lockdown. Europarl.

58. Ding, Y., Xu, J., Huang, S., Li, P., Lu, C., \& Xie, S. (2020). Risk perception and depression in public health crises: evidence from the COVID-19 crisis in China. International Journal of Environmental Research and Public Health, 17(16), 5728.

59. Douglas, M., Katikireddi, S. V., Taulbut, M., McKee, M., \& McCartney, G. (2020). Mitigating the wider health effects of Covid-19 pandemic response. BMJ, 369, m1557.

60. Duncan, E. (2020, March 27). NSW domestic violence support groups warn Coronavirus isolation is prompting surge in demand for services. $A B C$ Net.

61. Edwards, V. J., Holden, G. W., Felitti, V. J., \& Anda, R. F. (2003). Relationship between multiple forms of childhood 
maltreatment and adult mental health in community respondents: Results from the adverse childhood experiences study. The American Journal of Psychiatry, 160(8), 1453-1460.

62. Eklund, K., Meyer, L., \& Bosworth, K. (2018). Examining the role of school resource officers on school safety and crisis response teams. Journal of School Violence, 17(2), 139 - 151.

63. Elder, H. G., \& Conger, D. R. (2014). Children of the land: Adversity and success in rural America. The University of Chicago Press.

64. Evans, S. (2020, April 22). CCPD, SPD report recent rise in domestic violence calls. WTOC. Retrieved January 11, 2021.

65. Felitti, V. J., Anda, R. F., Nordenberg, D., Williamson, D. F., Spitz, A. M., Edwards, V., Koss, M. P., \& Marks, J. S. (1998). Relationship of childhood abuse and household dysfunction to many of the leading causes of death in adults: The Adverse Childhood Experiences (ACE) Study. American Journal of Preventive Medicine, 14(4), 245-258.

66. Felix, E. D., You, S., \& Canino, G. (2015). Family influences on the relationship between hurricane exposure and Ataques de Nervios. Journal of Child and Family Studies, 24(8), 22292240.

67. Finkelhor, D. (1983). Common features of family abuse. In Finkelhor, D., Gelles, R. J., Hotaling, G. T., \& Straus, M. A. (Eds.), The dark side of families: Current family violence research (pp. 17-28). SAGE Publications.

68. Finkelhor, D., Ormrod, R. K., \& Turner, H. A. (2007a). Polyvictimization: A neglected component in child victimization. Child Abuse \& Neglect, 31(1), 7-26.

69. Finkelhor, D., Ormrod, R. K., \& Turner, H. A. (2007b). Revictimization patterns in a national longitudinal sample of children and youth. Child Abuse \& Neglect, 31(5), 479-502.

70. Finzi-Dottan, R., \& Harel, G. (2014). Parents' potential for child abuse: An intergenerational perspective. Journal of Family Violence, 29(4), 397-408.

71. Fischer, H.T., Elliott, L,. \& Bertrand, S.L. (2018). Guidance note: Protection of children during infectious disease outbreaks. The Alliance for Child Protection in Humanitarian Action.

72. Fitz-Gibbon, K., \& Meyer, S. (2020, March 18). Coronavirus: Fear of family violence spike as COVID-19 impact hits households. Monash Lens University.

73. Folkman, S., \& Lazarus, R. S. (1986). Stress processes and depressive symptomatology. Journal of Abnormal Psychology, 95(2), 107.

74. Fortson, B. L., Klevens, J., Merrick, M. T., Gilbert, L. K., \& Alexander, S. P. (2016). Preventing child abuse and neglect: A technical package for policy, norm, and programmatic activities. National Center for Injury Prevention and Control, Centers for Disease Control and Prevention.

75. Fox, C. L., Corr, ML. Gadd, D., \& Sim, J. (2016). Evaluating the effectiveness of domestic abuse prevention education: Are certain children more or less receptive to the messages conveyed? Legal and Criminological Psychology, 21(1), $212-$ 227.

76. Frude, N. (1991). Understanding family problems: A psychological approach. John Wiley \& Sons.

77. Galea, S., Ahern, J., Resnick, H., Kilpatrick, D., Bucuvalas, M., Gold, J., \& Vlahov, D. (2002). Psychological sequelae of the September 11 terrorist attacks in New York City. The New England Journal of Medicine, 346, 982-987.

78. Galea, S., Merchant, R.M. \& Lurie, N. (2020). The mental health consequences of COVID-19 and physical distancing: The need for prevention and early intervention. JAMA Internal Medicine, 180(6), 817-818.
79. Gershoff, E. T., Lansford, J. E., Sexton, H. R., Davis - Kean, P., \& Sameroff, A. J. (2012). Longitudinal links between spanking and children's externalizing behaviors in a national sample of White, Black, Hispanic, and Asian American families. Child Development, 83(3), 838 - 843.

80. Gershoff, E. T., Lansford, J. E., Sexton, H. R., Davis-Kean, P., \& Sameroff, A. J. (2012). Longitudinal links between spanking and children's externalizing behaviors in a national sample of White, Black, Hispanic, and Asian American families. Child Development, 83(3), 838-843.

81. Gilbert, L. K., Breiding, M. J., Merrick, M. T., Thompson, W. W., Ford, D. C., Dhingra, S. S., \& Parks, S. E. (2015). Childhood adversity and adult chronic disease: An update from ten states and the District of Columbia, 2010. American Journal of Preventive Medicine, 48(3), 345-349.

82. Gilmore, D. (2010). Chronic child neglect: Building knowledge, fostering hope. Policy \& Practice, 68(3), 12-13.

83. Grattan, L. M., Roberts, S., Mahan Jr., W. T., McLaughlin, P. K., Otwell, S., \& Morris Jr., J. G. (2011). The early psychological impacts of the deep water horizon oil spill on Florida and Alabama communities. Environmental Health Perspectives, 119(6), 838-843.

84. Green P. (2020). Risks to children and young people during covid-19 pandemic. BMJ (Clinical Research Ed.), 369(8244), m1669.

85. Griffith A. K. (2020). Parental burnout and child maltreatment during the COVID-19 pandemic. Journal of Family Violence, 1-7. Advance online publication.

86. Haj-Yahia, M. M., Sokar, S., Hassan-Abbas, N., \& Malka, M. (2019). The relationship between exposure to family violence in childhood and post-traumatic stress symptoms in young adulthood: The mediating role of social support. Child Abuse \& Neglect, 92, 126-138.

87. Hatters Friedman, S., \& Resnick, P. J. (2007). Child murder by mothers: Patterns and prevention. World Psychiatry, 6(3), 137141.

88. Hayden, T. (2020, April 1). Santa Barbara Child Abuse Spikes Amid Coronavirus Lockdown. Santa Barbara Independent. Retrieved April 4, 2020.

89. Hennessy, M. (2020, May 20). 'Isolated at home with their tormentor': Childline experiences increase in call since closure of schools. The journal.

90. Herrenkohl, T. I., Sousa, C., Tajima, E. A., Herrenkohl, R. C., \& Moylan, C. A. (2008). Intersection of child abuse and children's exposure to domestic violence. Trauma, Violence, \& Abuse, 9(2), 84-99.

91. Hewitt, P. L., \& Flett, G. L. (1991). Perfectionism in the self and social contexts: Conceptualization, assessment, and association with psychopathology. Journal of Personality and social Psychology, 60(3), 456-470.

92. Hiraoka, D., \& Tomoda, A. (2020). Relationship between parenting stress and school closures due to the COVID-19 pandemic. Psychiatry and Clinical Neurosciences, 74(9), 497498.

93. Hollander, J. E., \& Carr, B. G. (2020). Virtually perfect? Telemedicine for Covid - 19. New England Journal of Medicine, 382(18), 1679 - 1681.

94. Holmes, E. A., O'Connor, R. C., Perry, V. H., Tracey, I., Wessely, S., Arseneault, L., Ballard, C., Christensen, H., Cohen Silver, R., Everall, I., Ford, T., John, A., Kabir, T., King, K., Madan, I., Michie, S., Przybylski, A. K., Shafran, R., Sweeney, A., Worthman, C. M., ... Bullmore, E. (2020). Multidisciplinary research priorities for the COVID-19 
pandemic: A call for action for mental health science. The Lancet, 7(6), 547-560.

95. Hubert, S., \& Aujoulat, I. (2018). Parental burnout: When exhausted mothers open up. Frontiers in Psychology, 9, 1021.

96. Humphreys, K.L. Myint, M.T. \& Zeanah, C.H. (2020). Increased risk for family violence during the COVID-19 pandemic. Pediatrics, 146(1), e20200982.

97. Joiner, T. R., Lieberman, A., Stanley, I. H., \& Reger, M. A. (2020). Might the COVID-19 pandemic spur increased murdersuicide? Journal of Aggression, Conflict and Peace Research, 12(3), 177-182.

98. Kaniasty, K., \& Norris, F. H. (1993). A test of the social support deterioration model in the context of natural disaster. Journal of Personality and Social Psychology, 64(3), 395-408.

99. Kennedy, S. (2020, April 6). Jobs destroyed worldwide as Coronavirus triggers deep recession. Japan times.

100. Kim, W. A., Nyengerai, T. \& Mendenhall, E. (2020). Evaluating the mental health impacts of the COVID-19 pandemic: Perceived risk of COVID-19 infection and childhood trauma predict adult depressive symptoms in urban South Africa. Psychological Medicine, 1-13.

101. Kimber, M., McTavish, J. R., Vanstone, M., Stewart, D. E., \& MacMillan, H. L. (2021). Child maltreatment online education for healthcare and social service providers: Implications for the COVID-19 context and beyond. Child Abuse \& Neglect, 116(Pt 2), 104743 .

102. Korzinski, D. (2020, March 24). COVID-19: Those least equipped to endure economic downturn bearing the brunt of layoffs. Angusreid.

103. Kovler, M. L., Ziegfeld, S., Ryan, L. M., Goldstein, M. A., Gardner, R., Garcia, A. V., \& Nasr, I. W. (2021). Increased proportion of physical child abuse injuries at a level I pediatric trauma center during the Covid-19 pandemic. Child Abuse \& Neglect, 116(2), 104756.

104. Lawson, M., Piel, M. H., \& Simon, M. (2020). Child maltreatment during the COVID-19 pandemic: Consequences of parental Job loss on psychological and physical abuse towards children. Child Abuse \& Neglect, 110(2), 104709.

105. Lee J. (2020). Mental health effects of school closures during COVID-19. The Lancet, 4(6), 421.

106. Lee, A. M., Wong, J., McAlonan, G. M., Cheung, V., Cheung, C., Sham, P. C., Chu, S. M., Wong, P. C., Tsang, K. W. T., \& Chua, S. E. (2007). Stress and psychological distress among SARS survivors 1 year after the outbreak. The Canadian Journal of Psychiatry, 52(4), 223240.

107. Lee, J. S., Romich, J. L., Kang, J. Y., Hook, J. L., \& Marcenko, M. O. (2017). The impact of income on reunification among families with children in out - of - home care. Children and Youth Services Review, 72, 91 - 99.

108. Lee, S. J., \& Ward, K. P. (2020). Stress and parenting during the coronavirus pandemic. University of Michigan.

109. Li, D., Chu, C. M., Ng, W. C., \& Leong, W. (2014). Predictors of re-entry into the child protection system in Singapore: A cumulative ecological-transactional risk model. Child Abuse \& Neglect, 38(11), 1801-1812.

110. Li, J. B., Yang, A., Dou, K., Wang, L. X., Zhang, M. C., \& Lin, X. Q. (2020). Chinese public's knowledge, perceived severity, and perceived controllability of COVID-19 and their associations with emotional and behavioural reactions, social participation, and precautionary behaviour: A national survey. BMC Public Health, 20(1), 1-14.

111. Lindo, J. M., Schaller, J., \& Hansen, B. (2018). Caution! Men not at work: Gender-specific labor market conditions and child maltreatment. Journal of Public Economics, 163, 77-98.
112. Lindström, C., Aman, J., \& Norberg, A. L. (2011). Parental burnout in relation to sociodemographic, psychosocial and personality factors as well as disease duration and glycaemic control in children with Type 1 diabetes mellitus. Acta Paediatrica, 100(7), 1011-1017.

113. Liu, S., Yang, L., Zhang, C., Xiang, YT, Liu, Z., Hu, S., \& Zhang, B. (2020). Online mental health services in China during the COVID - 19 outbreak. The Lancet, 7(4), E17 - E18.

114. Long, H., Van Dam, A., Fowers, A., \& Shapiro, L. (2020, September 30). The COVID-19 recession is the most unequal in modern U.S. history. The Washington Post.

115. Lopez, E. (21, July 2020). Amid pandemic, more than half of calls to national sexual assault are from children. 11Alive.

116. Luchetti, M., Lee, J. H., Aschwanden, D., Sesker, A., Strickhouser, J. E., Terracciano, A., \& Sutin, A. R. (2020). The trajectory of loneliness in response to COVID-19. American Psychologist, 75(7), 897-908.

117. Lundberg, M., \& Wuermli, A. (Eds). (2012). Children and youth in crisis: Protecting and promoting human development in times of economic shocks. The World Bank. Washington.

118. Luseno, W. K., Field, S. H., Iritani, B. J., Odongo, F. S., Kwaro, D., Amek, N. O., \& Rennie, S. (2021). Pathways to depression and poor quality of life among adolescents in Western Kenya: Tole of anticipated HIV stigma, HIV risk perception, and sexual behaviours. AIDS and Behaviour, 25(5), 1423-1437.

119. Mackenzie, M. J., Kotch, J. B., \& Lee, L. C. (2011). Toward a cumulative ecological risk model for the etiology of child maltreatment. Children and Youth Services Review, 33(9), 1638-1647.

120. MacNeil, S. (2020, March 31). Doctor warns of child abuse risks during pandemic, economic downturn. NBC Montana.

121. Making Caring Project. (2021). Relationship mapping strategy. Harvard Graduate School of Education.

122. Martinkevich, P., Larsen, L. L., Græsholt-Knudsen, T., Hesthaven, G., Hellfritzsch, M. B., Petersen, K. K., MøllerMadsen, B., \& Rölfing, J. D. (2020). Physical child abuse demands increased awareness during health and socioeconomic crises like COVID-19. Acta Orthopaedica, 91(5), 527-533.

123. Martín-María, N., Caballero, F. F., Miret, M., Tyrovolas, S., Haro, J. M., Ayuso-Mateos, J. L., \& Chatterji, S. (2020). Differential impact of transient and chronic loneliness on health status. A longitudinal study. Psychology \& Health, 35(2), 177195.

124. Maurage, P., Joassin, F., Philippot, P., Heeren, A., Vermeulen, N., Mahau, P., Delperdange, C., Corneille, O., Luminet, O., \& de Timary, P. (2012). Disrupted regulation of social exculsion in alcohol - dependence: An fMRI study. Neuropsychopharmacology, 37(9), 2067 - 2075.

125. McLaughlin, K. A., Conron, K. J., Koenen, K. C., \& Gilman, S. E. (2010). Childhood adversity, adult stressful life events, and risk of past-year psychiatric disorder: A test of the stress sensitization hypothesis in a population-based sample of adults. Psychological Medicine, 40(10), 1647-1658.

126. McLaughlin, K. A., Weissman, D., \& Bitrán, D. (2019). Childhood adversity and neural development: A systematic review. Annual Review of Developmental Psychology, 1, 277312.

127. Meyer, S. (2020, April 9). COVID-19: The bystander role has never been more critical in calling out family violence. Monash Lens University.

128. Mikolajczak, M., Brianda, M. E., Avalosse, H., \& Roskam, I. (2018a). Consequences of parental burnout: Its specific effect on child neglect and violence. Child Abuse \& Neglect, 80(1), $134-145$ 
129. Mikolajczak, M., Gross, J. J., \& Roskam, I. (2019). Parental burnout: What is it, and why does it matter? Clinical Psychological Science, 7(6), 1319-1329.

130. Mikolajczak, M., Raes, M. E., Avalosse, H., \& Roskam, I. (2018b). Exhausted parents: Sociodemographic, child-related, parent-related, parenting and family-functioning correlates of parental burnout. Journal of Child and Family Studies, 27(2), 602-614.

131. Miller, G. (2020, March 16). Social distancing prevents infections, but it can have unintended consequences. Sciencemag.

132. Miller, T. W., \& Kraus, R. F. (1994). Natural and environmental disasters: Psychological issues and clinical responses. Integrative Psychiatry, 10(3), 128-132.

133. Morese, R., Palermo, S., Defedele, M., Nervo, J., \& Borraccino, A. (2019). Vulnerability and social exclusion: Risk in adolescence and old age. In R. Morese, \& S. Palermo (Eds), The new forms of social exclusion (pp. 1 - 6). Intech.

134. Mulvey, K. L., Boswell, C., \& Zheng, J. (2017). Causes and consequences of social exclusion and peer rejection among children and adolescents. Report on Emotional \& Behavioral Disorders in Youth, 17(3), 71 - 75.

135. Müller, N., Krause, D., Barth, R., Myint, A. M., Weidinger, E., Stettinger, W., Zill, P., Drexhage, H., \& Schwarz, M. J. (2019). Childhood adversity and current stress are related to pro-and anti-inflammatory cytokines in major depression. Journal of Affective Disorders, 253, 270-276.

136. Naccarato, L. (2020, March 17). COVID-19 has Kids Help Phone calling for more volunteers as services swamped with calls. CBC News.

137. National Centre for Health Statistics. (2012). Healthy people 2010: Final review. U.S. Department of Health and Human Services. Washington.

138. National Research Council. (1993). Chapter 5: Prevention. In National Research Council, Understanding Child Abuse and Neglect. The National Academies Press.

139. National Society for the Prevention of Cruelty to children. (n.d.). Coronavirus (COVID-19) and keeping children safe from abuse. NSPCC.

140. Nau, M. D. (2016). Whose financial crisis? How the great recession reshaped economic instability and inequality in the U.S. (Doctoral dissertation).

141. Newman, K. L. S. (2012). Shut up: Bubonic plague and quarantine in early modern England. Journal of Social History, 45(3), $809-834$.

142. Newman, T., \& Blackburn, S. (2002). Transitions in the lives of children and young people: Resilience factors: Interchange 78. Scottish Executive Education Department.

143. Norman, R. E., Byambaa, M., De, R., Butchart, A., Scott, J., \& Vos, T. (2012). The long-term health consequences of child physical abuse, emotional abuse, and neglect: A systematic review and meta-analysis. PLoS Medicine, 9(11), e1001349.

144. North Texas hospital reports spike in severe child abuse cases; Believe linked to stress from Coronavirus Pandemic. (2020, March 20). CBS Local. Retrieved July 2, 2021.

145. Oliver, E. (2014). Zero violence since early childhood: The dialogic recreation of knowledge. Qualitative Inquiry, 20(7), 902-908.

146. Oosterman, M., Schuengel, C., Forrer, M. L., \& De Moor, M. H. (2019). The impact of childhood trauma and psychophysiological reactivity on at-risk women's adjustment to parenthood. Development and Psychopathology, 31(1), 127141.
147. Opel, N., Redlich, R., Zwanzger, P., Grotegerd, D., Arolt, V., Heindel, W., Konrad, C., Kugel, H., \& Dannlowski, U. (2014). Hippocampal atrophy in major depression: A function of childhood maltreatment rather than diagnosis? Neuropsychopharmacology, 39(12), 2723-2731.

148. Panadero, S., Vázquez, J. J., \& Martin, R. M. (2016). Alcohol, poverty and social exclusion: Alcohol consumption among the homeless and those at risk of social exclusion in Madrid. Adicciones, 29(1), 33 - 36.

149. Parker, K., Horowitz, J. M., \& Brown, A. (2020, April 21). About half of lower-income Americans report household job or wage loss due to COVID-19. Pew Research Center.

150. Partap, A., Coffman, J., \& Camp, T. (2020, May 1). Child abuse rising in Fort Worth amid Coronavirus: Here's what you can do to help. Star-Telegram.

151. Pelton, L. H. (2015). The continuing role of material factors in child maltreatment and placement. Child Abuse \& Neglect, 41, $30-39$.

152. Peterman, A., Potts, A., O’Donnell, M., Thompson, K., Shah, N., Oertelt-Prigione, S., \& van Gelder, N. (2020). Pandemics and violence against women and children (Working Paper No. 528). Center for Global Development.

153. Peterson, C., \& Seligman, M. E. (1983). Learned helplessness and victimization. Journal of Social Issues, 39(2), 103-116.

154. Peterson, C., Florence, C., \& Klevens, J. (2018). The economic burden of child maltreatment in the United States, 2015. Child Abuse \& Neglect, 86, 178-183.

155. Pew Research Center (2020). Most Americans say Coronavirus outbreak has impacted their lives. Per Social Trends.

156. Pierce, G. R., Sarason, B. R., \& Sarason, I. G. (1992). General and specific support expectations and stress as predictors of perceived supportiveness: An experimental study. Journal of Personality and Social Psychology, 63(2), 297-307.

157. Pitt, S. (2020, April 23). Crisis calls from P.E.I. kids to help line increase $70 \%$ during pandemic. CBC News.

158. Platoff, E. (2020, March 27). Out of sight, child abuse in Texas thought to be on the rise. The Texas Tribune. Retrieved April 4, 2020.

159. Posick, C., Schueths, A. A., Christian, C., Grubb, J. A. \& Christian, S. E. (2020). Child victim services in the time of COVID-19: New challenges and innovative solutions. American Journal of Criminal Justice, 45, 680 - 689.

160. Quadara, A., Nagy, V., Higgins, D., \& Siegel, N. (2015). Conceptualising the prevention of child sexual abuse: Final report (Research Report No. 33). Australian Institute of Family Studies.

161. Quiroz, H. J., Parreco, J., Easwaran, L., Willobee, B., Ferrantella, A., Rattan, R., Thorson, C. M., Sola, J. E., \& Perez, E. A. (2020). Identifying populations at risk for child abuse: A nationwide analysis. Journal of Pediatric Surgery, 55(1), 135139.

162. RAINN. (20, April 2020). The national hotline consortium open letter to COVID-19.

163. Raphael, J. L., Zhang, Y., Liu, H., \& Giardino, A. P. (2010). Parenting stress in US families: Implications for paediatric healthcare utilization. Child Care, Health and Development, $36(2), 216-224$.

164. Reuters. (2020, March 13). As domestic abuse rises in lockdown, France to fund hotel rooms. Aljazeera.

165. Richards, L. (2009). Domestic abuse, stalking and harassment and honour based violence (DASH, 2009) risk identification assessment and management model. Association of the Chemical Profession of Ontario [ACPO], \& Coordinated Action against Domestic Abuse [CAADA]. 
166. Roca, E., Melgar, P., Gairal-Casadó, R., \& Pulido-Rodríguez, M. A. (2020). Schools that 'open doors' to prevent child abuse in confinement by COVID-19. Sustainability, 12(11), 4685.

167. Rodriguez C. M. (2010). Parent-child aggression: Association with child abuse potential and parenting styles. Violence and Victims, 25(6), 728-741.

168. Rosenthal, C. M. \& Thompson, L. A. (2020). Child abuse awareness month during the Coronavirus disease 2019 pandemic. JAMA Pediatrics, 174(8).

169. Roskam, I., Brianda, M. E., \& Mikolajczak, M. (2018). A step forward in the conceptualization and measurement of parental burnout: The Parental Burnout Assessment (PBA). Frontiers in Psychology, 9, 758.

170. Rovner, B. W., Haller, J. A., Casten, R. J., Murchison, A. P., \& Hark, L. A. (2014). Depression and risk perceptions in older African Americans with diabetes. Diabetes Spectrum, 27(2), 114-118.

171. Rudolph, J., \& Zimmer-Gembeck, M. J. (2018). Reviewing the focus: A summary and critique of child-focused sexual abuse prevention. Trauma, Violence \& Abuse, 19(5), 543-554.

172. Rutter, M., Kent, M. W., \& Rolf, J. G. (1979). Primary prevention of psychopathology, vol. 3: Social competence in children. Psychiatric Services, 31(4), 279 - 280.

173. Rutter, M., Tizard, J., Yule, W., Graham, P., \& Whitmore, K. (1976). Research report: Isle of Wight Studies, 1964-1974. Psychological Medicine, 6(2), 313-332.

174. Sacks, V. H., \& Murphey, D. (2018). The prevalence of adverse childhood experiences, nationally by, by state, and by racelethnicity. Child Trends.

175. Sameroff, A. J. (2000). Dialectical processes in developmental psychopathology. In Sameroff, A., Lewis, M. \& Miller, S. (Eds), Handbook of developmental psychopathology (pp. 2340).

176. Sameroff, A., Seifer, R., Zax, M., \& Barocas, R. (1987). Early indicators of developmental risk: Rochester Longitudinal Study. Schizophrenia Bulletin, 13(3), 383-394.

177. Schenck-Fontaine, A., \& Gassman-Pines, A. (2020). Income inequality and child maltreatment risk during economic recession. Children and Youth Services Review, 112, 104926.

178. Schenck-Fontaine, A., Gassman-Pines, A., \& Hill, Z. (2017). Use of informal safety nets during the supplemental nutrition assistance program benefit cycle: How poor families cope with within-month economic instability. Social Service Review, 91(3), 456-487.

179. Schmidt, S., \& Natanson, H. (2020, April 30). With kids stuck at home, ER doctors see more severe cases of child abuse. The Washington Post. Retrieved January 11, 2021.

180. Schneider, D., Harknett, K., \& McLanahan, S. (2016). Intimate partner violence in the great recession. Demography, 53(2), 471-505.

181. Schneider, W., Waldfogel, J., \& Brooks - Gunn, J. (2013). The great recession and risk for child abuse and neglect. Child and Youth Services Review, 37(10), 721 - 729.

182. Scott, K. M., Smith, D. R., \& Ellis, P. M. (2010). Prospectively ascertained child maltreatment and its association with DSMIV mental disorders in young adults. Archives of General Psychiatry, 67(7), 712-719.

183. Seddighi, H., Salmani, I., Javadi, M. H., \& Seddighi, S. (2021). Child abuse in natural disasters and conflicts: A systematic review. Trauma, Violence \& Abuse, 22(1), 176-185.

184. Seiglie, C. (2004). Understanding child outcomes: An application to child abuse and neglect. Review of Economics of the Household, 2(2), 143-160.
185. Simione, L., \& Gnagnarella, C. (2020). Differences between health workers and general population in risk perception, behaviors, and psychological distress related to COVID-19 spread in Italy. Frontiers in Psychology, 11, 2166.

186. Sinha, I. P., Harwood, R., Semple, M. G., Hawcutt, D. B., Thursfield, R., Narayan, O., Kenny, S. E., Viner, R., Hewer, S. L., \& Southern, K. W. (2020). COVID-19 infection in children. The Lancet Respiratory Medicine, 8(5), 446-447.

187. Sistovaris, M., Miller, S., Collin-Vezina, D., \& Fallon, B. (2020, April 3). Child welfare and pandemics: What we know and what we can do [PowerPoint slides]. ISPCAN.

188. Sorkkila, M., \& Aunola, K. (2020). Risk factors for parental burnout among Finnish parents: The role of socially prescribed perfectionism. Journal of Child and Family Studies, 29(3), 648659.

189. Sousa, C., Herrenkohl, T. I., Moylan, C. A., Tajima, E. A., Klika, J. B., Herrenkohl, R. C., \& Russo, M. J. (2011). Longitudinal study on the effects of child abuse and children's exposure to domestic violence, parent-child attachments, and antisocial behavior in adolescence. Journal of Interpersonal Violence, 26(1), 111-136.

190. Spinelli, M., Lionetti, F., Pastore, M., \& Fasolo, M. (2020). Parents' stress and children's psychological problems in families facing the COVID-19 outbreak in Italy. Frontiers in Psychology, 11, 1713.

191. Sprague, C.M., Kia-Keating, M., Felix, E., Afifi, T., Reyes, G., \& Afifi, W. (2015). Youth psychosocial adjustment following wildfire: The role of family resilience, emotional support, and concrete support. Child Youth Care Forum, 44(3), 433-450 (2015).

192. Sriskandarajah, V., Neuner, F., \& Catani, C. (2015). Predictors of violence against children in Tamil families in northern Sri Lanka. Social Science \& Medicine (1982), 146, 257-265.

193. Stark, E. (2009). Coercive control: The entrapment of women in personal life. Oxford University Press.

194. Steinberg, L. D., Catalano, R., \& Dooley, D. (1981). Economic antecedents of child abuse and neglect. Child Development, 52(3), 975-985.

195. Stith S.M., Liu T., Davies C., Boykin E.L., Alder M.C., Harris J.M. (2009). Risk factors in child maltreatment: A metaanalytic review of the literature. Aggression and Violence Behavior, 14(1), 13-29.

196. Stith, S. M., Liu, T., Davies, L. C., Boykin, E. L., Alder, M. C., Harris, J. M., Som, A., McPherson, M., \& Dees, J. E. M. E. G. (2009). Risk factors in child maltreatment: A meta-analytic review of the literature. Aggression and Violent Behavior, 14(1), 13-29.

197. Swedo, E., Idalkkadar, N., Leemis, R., Dias, T., Radhakrishman, L., Stein, Z., Chen, M., Agathis, N., \& Holland, K. (2020). Trends in U.S. emergency department visits related to suspected or confirmed child abuse and neglect among children and adolescents aged $<18$ years before and during the COVID-19 pandemic - United States, January 2019 - September 2020. Morbidity and Mortality Weekly Report (MMWR), 69(49), 1841-1847.

198. Séjourné, N., Sanchez-Rodriguez, R., Leboullenger, A., \& Callahan, S. (2018). Maternal burn-out: an exploratory study. Journal of Reproductive and Infant Psychology, 36(3), 276288.

199. Taub, A. (2020, April 6). A new Covid - 19 crisis: Domestic abuse rises worldwide. The New York Times. Retrieved January 11, 2021.

200. Teicher, M. H., Samson, J. A., Anderson, C. M., \& Ohashi, K. (2016). The effects of childhood maltreatment on brain 
structure, function and connectivity. Nature Reviews Neuroscience, 17(10), 652.

201. Tener, D., \& Sigad, L. (2019). "I felt like I was thrown into a deep well": Educators coping with child sexual abuse disclosure. Children and Youth Services Review, 106, 104465.

202. Thapa, A., Cohen, J., Guffey, S., \& Higgins-D'Alessandro, A. (2013). A review of school climate research. Review of Educational Research, 83(3), 357-385.

203. The Alliance for Child Protection in Humanitarian Action. (2019). Technical note: Protection of children during the coronavirus pandemic (V.1).

204. The National Centre for Injury Prevention and Control (NCIPC), Division of Violence Prevention. (2020). Risk and protective factors.

205. Thornton, J. (2020). COVID-19: A\&E visits in England fall by $25 \%$ in week after lockdown. BMJ (Clinical Research Ed.), 369(8241), m1401.

206. Tobin, G. A., \& Ollenburger, J. C. (1996). Predicting levels of postdisaster stress in adults following the 1993 floods in the upper midwest. Environment and Behavior, 28, 340-357.

207. Tracy, M., Norris, F. H., \& Galea, S. (2011). Differences in the determinants of posttraumatic stress disorder and depression after a mass traumatic event. Depression \& Anxiety, 28(8), 666 -675 .

208. Turner, S. G., \& Maschi, T. M. (2015). Feminist and empowerment theory and social work practice. Journal of Social Work Practice, 29(2), 151-162.

209. Tutten, J. (2020, March 31). Coronavirus: Florida child abuse, domestic violence hotlines see surge of calls in March. WFTV. Retrieved April 4, 2020.

210. UN News. (2020, April 14). Online predators put millions of children at risk during COVID-19 pandemic lockdown. UN News.

211. UNICEF. (2020, March 20). COVID - 19: Children at heightened risk of abuse, neglect, exploitation and violence amidst intensifying containment measures.

212. UNICEF. (2020, March 25). COVID-19: Children at heightened risk of abuse, neglect, exploitation and violence amidst intensifying containment measures.

213. United Nations. (2009). 2009 UNISDR terminology on disaster risk reduction. United Nations International Strategy for Disaster Reduction.

214. Usher, K., Bhullar, N., Durkin, J. \& Jackson, D. (2020). Family violence and COVID-19: Increased vulnerability and reduced options for support. International Journal of Mental Health, 29(4), 549-552.

215. van Gelder, N., Peterman, A., Potts, A., O'Donnell, M., Thompson, K., Shah, N., Oertelt-Prigione, S., \& Gender and COVID-19 working group (2020). COVID-19: Reducing the risk of infection might increase the risk of intimate partner violence. EClinicalMedicine, 21, 100348.

216. Vu, N. L., Jouriles, E. N., McDonald, R., \& Rosenfield, D. (2016). Children's exposure to intimate partner violence: A meta-analysis of longitudinal associations with child adjustment problems. Clinical Psychology Review, 46, 25-33.

217. Wagers, S. M. (2020, April 8). Domestic violence growing in wake of Coronavirus outbreak. The Conversation.

218. Walsh, K., Zwi, K., Woolfenden, S., \& Shlonsky, A. (2018). School-based education programs for the prevention of child sexual abuse: A Cochrane systematic review and meta-analysis. Research on Social Work Practice, 28(1), 33-55.

219. Wang, C., Pan, R., Wan, X., Tan, Y., Xu, L., McIntyre, R. S., Choo, F. N., Tran, B., Ho, R., Sharma, V. K., \& Ho, C. (2020). A longitudinal study on the mental health of general population during the COVID-19 epidemic in China. Brain, Behavior, and Immunity, 87, 40-48.

220. Wekerle, C., Wolfe, D. A., Dunston, J., \& Alldred, T. (2014). Child maltreatment. In E. J. Mash \& R. A. Barkley (Eds.), Child psychopathology (pp. 737-798, 3rd ed.). The Guilford Press.

221. Welch, M., \& Haskins, R. (2020). What COVID-19 means for America's child welfare system. Brookings.

222. Widom, C. S., Czaja, S., \& Dutton, M. A. (2014). Child abuse and neglect and intimate partner violence victimization and perpetration: A prospective investigation. Child Abuse \& Neglect, 38(4), 650-663.

223. Woodall, C. (2020, May 13). As hospitals see more severe child abuse injuries during coronavirus, 'the worst is yet to come'. USA Today. Retrieved January 11, 2021.

224. World Health Organization [WHO]. (2020a, June 8). Child maltreatment.

225. World Health Organization [WHO]. (n.d.). Home. Retrieved February 21, 2020.

226. World Health Organization. (2020b). Global status report on preventing violence against children 2020.

227. Yetter, D. (2020, March 18). Kentucky is limiting in - person child abuse investigations because of the coronavirus. Courier Journal.

228. Zeuthen, K., \& Hagelskjær, M. (2013). Prevention of child sexual abuse: Analysis and discussion of the field. Journal of Child Sexual Abuse, 22(6), 742-760.

229. Zhong, B., Chen, S., \& Conwell, Y. (2016). Effects of transient versus chronic loneliness on cognitive function in older adults: Findings from the Chinese longitudinal healthy longevity survey. The American Journal of Geriatric Psychiatry, 24(5), 389-398.

230. Zimmerman, M. A. (2000). Empowerment theory. In handbook of community psychology (pp. 43-63). Springer.

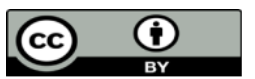

This work is licensed under Creative Commons Attribution 4.0 License
To Submit Your Article Click Here: Submit Manuscript

DOI: $10.31579 / 2690-1919 / 201$ 